\title{
The Implications of the Acquisition of a New Nationality for the Right of Return of Palestinian Refugees
}

\author{
Mazen MASRI* \\ City University London, United Kingdom \\ Mazen.masri.I@city.ac.uk
}

\begin{abstract}
This paper examines the legal consequences of the acquisition of a new nationality for the right of return of Palestinian refugees. The paper argues that since the right of return is independent of refugee status, the cessation of the latter should not necessarily abrogate the former. By examining the underpinnings of the right of return to one's own country, especially the link between the individual and her territory, this paper argues that this link is somehow weakened in a situation of naturalization in a different country. However, this weakening of the link should not automatically lead to the deprivation of rights. The circumstances that lead refugees to leave their country of origin, the circumstances preventing their return, and the decisions made by the individuals in view of their available options, should be examined.
\end{abstract}

Much of the discussion about Palestinian refugees displaced in $1948^{\mathrm{I}}$ has focused on the question of their right to return to the areas they were displaced from (what is

\footnotetext{
* PhD, Osgoode Hall Law School, York University. Lecturer, The City Law School, City University London. I wish to thank Obiora Okafor, Susan Akram, Jeff Handmaker, Ingrid Jaradat Gassner, and Sujith Xavier for their comments on earlier drafts. Any errors or omissions are mine.

I. Over the past sixty-five years, Palestinians have become the victims of many waves of displacement as a result of wars, political instability, and Israeli state policies. According to a survey, about 7.4 million Palestinians have been forcibly displaced since 1948 . Those displaced fall within four main categories: (i) those displaced during and as a result of the 1948 war (usually referred to as Palestinian refugees or Palestine refugees); (ii) those displaced during and as a result of the I967 war (usually referred to as "displaced persons"); and (iii) those who were displaced outside the area of Palestine who are neither I 967 refugees nor I948 refugees. The fourth category refers to Internally Displaced Persons (IDP), who were internally displaced within Israel in 1948 , or in the Occupied Palestinian Territories during and after the 1967 war. See BADIL, "Survey of Palestinian Refugees and Internally Displaced Persons 20Iо-20I2: Volume VII" (20I2), online: BADIL < http://www.badil.org/en/press-releases/I42-20I2/ 3638-press-eng-53> [Survey of Palestinian Refugees]. The focus of this paper is the first category, that is, Palestinians displaced during and as a result of the I948 war. As of 20I2, this amounted to 5.8 million refugees, 4.8 million of whom are registered with the United Nations Relief and Works Agency for Palestine Refugees. For detailed historical accounts on the issue of Palestinian refugees, see Benny MORRIS, The Birth of the Palestinian Refugee Problem Revisited (Cambridge: Cambridge University Press, 2004); Walid KHALIDI, "Why Did the Palestinians Leave, Revisited" (2005) 34 Journal of Palestine Studies 42; Ilan PAPPE, The Ethnic Cleansing of Palestine (Oxford: One World, 2007). For a detailed analysis of the political underpinnings of the Israeli policies which led to the different waves of displacement, see Nur MASALHA, Expulsion of the Palestinians: The Concept of "Transfer" in
} 
now Israel), which they see as their homeland. Many have made the case for the right of return based on a wide range of international law instruments, and emphasized the importance of this right as a central pillar for resolving the Palestinian refugee problem and achieving a peaceful resolution of the Israeli-Arab conflict. ${ }^{2}$ Others have argued that such a right does not exist, or, if it does exist, it does not apply to Palestinian refugees who were displaced in 1948 because of the particularities of their situation, the context of the war which led to their flight, subsequent developments in the region, security considerations, and the demographic changes that have happened since then. ${ }^{3}$ Sixty-five years have passed since the beginning of the Palestinian refugee problem, and due to the long period of time that has elapsed, many Palestinian refugees have since acquired a new nationality. Some had acquired their nationality according to the legislation of certain states. ${ }^{4}$ The acquisition of a new nationality in the case of refugees results in the cessation of refugee status according to Article ${ }_{\mathrm{I}} \mathrm{C}$ of the I95I Convention Relating to the Status of Refugees (I95I Convention). ${ }^{5}$ When refugee status is terminated as a result of the acquisition of a new citizenship, the question of the implications for the right of this group of people to return to their country of origin arises. This paper thus aims at answering this question as it relates to Palestinian refugees expelled or displaced during the 1948 war.

International refugee law contemplates three possible solutions for the refugee problem: voluntary repatriation, resettlement, and assimilation. ${ }^{6}$ The I95 I Convention

Zionist Political Thought I882- 1948 (Washington, DC: Institute of Palestine Studies, I992); Nur MASALHA, A Land Without a People: Israel, Transfer and the Palestinians 1949-96 (London: Faber and Faber, I997).

2. W. Thomas MALLISON and Sally MALLISON, An International Law Analysis of the Major United Nations Resolutions Concerning the Palestine Question, published at the request of the Committee on the Exercise of the Inalienable Rights of the Palestinian People, UN Doc. ST/SG/SER.F/4; Kathleen LAWAND, "The Right to Return of Palestinians in International Law" (I996) 8 International Journal of Refugee Law 532; John QUIGLEY, "Displaced Palestinians and a Right of Return" (I998) 3 Harvard International Law Journal I7I; Susan AKRAM and Terry REMPEL, "Recommendations for Durable Solutions for Palestinians Refugees" (2000-OI) I I Palestine Yearbook of International Law I; Gail BOWLING, The 1948 Palestinian Refugees and the Individual Right of Return: An International Law Analysis (Bethlehem: BADIL Resource Center, 2007); Victor KATTAN, "The Nationality of Denationalized Palestinians” (2005) 74 Nordic Journal of International Law 67.

3. See, for example, Kurt Rene RADLEY, “The Palestinian Refugees: The Right of Return in International Law" (I978) 72 American Journal of International Law 586; Ruth LAPIDOTH, "The Right of Return in International Law, with Special Reference to the Palestinian Refugees" (I986) I6 Israel Yearbook of Human Rights I03; Justus WEINER, “The Palestinian Refugees' 'Right to Return' and the Peace Process" (I997) 20 Boston College International and Comparative Law Review I; Lewis SAIDEMAN, "Do Palestinian Refugees have a Right of Return to Israel? An Examination of the Scope of and Limitations on the Right of Return" (2004) 44 Virginia Journal of International Law 829; Na'ama CARMI, "Immigration and Return: The Israeli Palestinian Case" (2005) 32 Philosophia 2I; Yaffa ZILBERSHATS, "International Law and the Palestinian Right of Return to the State of Israel" in Eyal BENVENISTI et al., eds., Israel and the Palestinian Refugees (Heidelberg: Max Planck Institute, 2007), I9I; Andrew KENT, "Evaluating the Palestinians' Claimed Right of Return” (20I2- I3) 34 University of Pennsylvania Journal of International Law I49.

4. Jordan, for example, bestowed nationality on Palestinian refugees according to the Jordanian Nationality Law of 1954. See Lex TAKKENBERG, The Status of Palestinian Refugees in International Law (Oxford: Oxford University Press, I998) at I 55.

5. Convention Relating to the Status of Refugees, 28 July I95 I, I89 U.N.T.S. I 50 (entered into force 22 April 1954) [195I Convention].

6. Statute of the Office of the United Nations High Commissioner on Refugees, GA Res. 427(V), U.N. Doc. A/I775 (I950), at para. I. 
provides that with the realization of one of these three solutions, refugee status will come to an end, as prescribed in Article ${ }_{\mathrm{I}} \mathrm{C}$. The last two solutions raise the issue of the implications of the acquisition of citizenship on the right of a refugee to return to her country of origin. This question becomes more important and critical especially in situations in which the refugee has lost the citizenship of her country of origin, as in the case of the Palestinian refugees. ${ }^{7}$

Does the cessation of refugee status of a Palestinian refugee as a result of the acquisition of citizenship preclude the right to return to her country of origin? It could be argued that since refugee law merely requires the facilitation of the voluntary repatriation of refugees and does not explicitly create the right to return, ${ }^{8}$ the cessation of refugee status does not affect this right. Nowak, for example, asserts that:

As soon as the political situation in the country of origin of refugees or displaced persons improves, and these persons wish to return to their "original home country", the establishment of a "second home country" must not be invoked for the purpose of preventing them from returning home, even if masses of people are claiming this right. ${ }^{9}$

On the other hand, it was argued in the context of the Palestinian refugees who have acquired a new nationality that the "[o]peration of Article ${ }_{\mathrm{I}} \mathrm{C}$ [of the Refugee Convention] (acceptance of new citizenship) terminates the right of return because the Palestinians' 'own country' under article I 2 (4) of the ICCPR is their country of new nationality, not Israel". ${ }^{\text {10 }}$ The rationale behind this reasoning is:

Conventions and laws in general ought to be interpreted in a plain language manner that harmonizes them rather than in a manner that places them at odds with each other. If a refugee has accepted new nationality, he now has a place that he can "enter" and call home; his new state of protection is his "own country". A previously stateless person who has accepted new citizenship should be seen as having a country he can call his "own". Once he has a country he can call his own, the former refugee has a right of return to that new country of which he is a national, not his former country, in this case Israel. ${ }^{\mathrm{II}}$

This position is based on a specific reading of two international law rules: one based on Article I2(4) of the International Covenant on Civil and Political Rights (ICCPR), ${ }^{\text {2 }}$

7. Palestinian refugees were citizens of Mandate Palestine according to the Palestine Citizenship Order, Official Gazette, I6 September I925, 460-78 [Palestine Citizenship Order]. According to the rules of state succession, persons who are habitual residents of a new state ipso facto become nationals of that state, and therefore Palestinians, who were habitual residents of territories that fell under Israeli control, a category which includes the Palestinian refugees, were entitled to Israeli nationality. The Palestinian refugees were denationalized en masse in 1952 in a discriminatory manner after Israel enacted the Citizenship Act-1952 [Citizenship Act-1952], which regulates matters related to nationality in Israel. See Kattan, supra note 2.

8. See art. I, Statute of the Office of the United Nations High Commissioner for Refugees, Annex to GA Res. A/RES/428(V), UN Doc. A/I775 (I950) [UNHCR Statute].

9. Manfred NOWAK, UN Covenant on Civil and Political Rights: CCPR Commentary (Kehl: N.P. Engel Verlag, 2005) at 288 (emphasis added).

Io. Saideman, supra note 3 at 863 .

II. Ibid.

I2. International Convention on Civil and Political Rights, I9 December I966, 999 U.N.T.S I7I (entered into force 23 March 1976) [ICCPR]. Israel signed the ICCPR on I9 December I966 and ratified it on 3 October I991. 
while the second is based on the cessation clause of the I95 I Convention, in an approach which seeks to harmonize different provisions of international law in order to create a coherent body of rules. Another commentator, Yaffa Zilbershats, has argued, in the context of Article I2(4) of the ICCPR, that the lapse of time since the displacement of the Palestinian refugees has rendered any effective link to Israel artificial, and that "Palestinians have much more stronger effective links to the states, in which they have resided for decades". ${ }^{13}$ This in turn means that Israel is not "their own country", and therefore they do not have a right to enter Israel according to the ICCPR because such a right would apply only to those who have effective links with Israel, which Palestinian refugees lack. ${ }^{\mathrm{I}}$

Only a very small number of authors, who argue that the I948 Palestinian refugees do have the right to return based on international human rights law, have touched upon the issue of the acquisition of a new citizenship. Those who did touch upon the issue, however, did so in passing. Kathleen Lawand, for example, does not tackle the issue of the acquisition of citizenship directly, but provides an elaborate analysis of the meaning of the term "his own country", based on the Nottebohm case and the effective link between the individual and the state. ${ }^{15}$ Her focus is on the effect of time on the genuine link. In this regard, she sees the passage of time as a factor eroding the genuine link, but adds that the actions of the state of origin should also be taken into consideration. ${ }^{16}$ Her paper was published before the United Nations (UN) Human Rights Committee issued its General Comment on Article I 2 of the ICCPR and its decision in Charles Stewart $v$. Canada. ${ }^{17}$ John Quigley also deals with the issue only in the context of the Palestinian refugees in Jordan. While he states that "seeking nationality elsewhere might be taken as a waiver of the individual's right to his original nationality", ${ }^{18}$ he argues, based on the circumstances in which Jordan had granted nationality to the Palestinian refugees, that there was no intention by the refugees to renounce their connection to Palestine. ${ }^{19}$ His analysis of the issue, however, is limited and cannot be used to assess the rights of other Palestinian refugees or former refugees.

This paper thus aims to provide an in-depth analysis of the impact of the acquisition of new nationality on the right of return of the Palestinian refugees. This question has arisen periodically, most recently in the attempts to admit the "State of

\footnotetext{
I3. Zilbershats, supra note 3 at 202.

14. Zilbershats quotes Kathleen Lawand to demonstrate that the effective link between the Palestinian refugees and Israel has weakened because of the long period of time that has elapsed since displacement. She neglects to deal with the argument by Lawand that the lapse of time must take into account "the reasons for the non-exercise of return during the said period". See Lawand, supra note 2 at 556.

I 5. Nottebohm Case (second phase) (Liechtenstein v. Guatemala), [I955] I.C.J. Rep. 4 [Nottebohm].

I6. Lawand, supra note 2 at 557.

17. Charles E. Stewart v. Canada, Human Rights Committee Communication No. 538/ı993, UN Doc. CCPR/C/58/1993 (I996) [Stewart v. Canada].

I8. Quigley, supra note 2 at 2I6. Takkenberg asserts that Palestinian refugees in Jordan are no longer considered refugees under the I95 I Convention, but they are still eligible to exercise the right to return. However, he does not provide a detailed explanation as to why this is so. See Takkenberg, supra note 4 at 128 .
}

I9. Quigley, supra note 2 at 217. 
Palestine" to the UN in 20I I and 20I2. The impact of the admission to the UN on the Palestinian refugees and their rights was part of the debate on the effectiveness of this initiative and its potential shortcomings. ${ }^{20}$

The paper will examine the different sources of the right of return, and will focus on international human rights law, mainly Article I2(4) of the ICCPR, the general comments of the United Nations Human Rights Committee, and other applicable instruments. It will examine if there is a conflict between international refugee law and the ICCPR on this issue, and, if there is one, a possible way to reconcile the conflict. The paper will argue that the establishment of a new home country or the acquisition of a new citizenship does not nullify the right of return. It will provide a conceptual basis for this argument in relation to Palestinian refugees, and at the same time elucidate the relationship between international refugee law and general international human rights law. The issues dealt with in this paper may be relevant to other refugee situations such as the Nepali-speaking refugees from Bhutan. ${ }^{21}$

Section I of the paper will begin with a brief discussion of the right of refugees to return to their country of origin and the different sources of law on which this right could be based. This section will focus on the right of return under international human rights law, in particular Article I2(4) of the ICCPR, because it appears to be the strongest and the least disputed source of this right. The concept of "one's own country" in Article I2(4) will be examined in Section II. Section III will focus on the I95 I Convention, its applicability and relevance to the Palestinian refugees, and the meaning and implications of the cessation of refugee status. Finally, Section IV will sum up the discussion and provide a model that would cohere with international human rights law.

\section{THE SOURCES OF THE RIGHT OF RETURN}

\section{A. The Right of Return Under International Law}

The right of an individual to return to her country is part of the broader concept of freedom of movement. Freedom of movement encompasses a broad range of human rights that include the right to leave or enter a state, and the right to reside in a state. It is seen as "an indispensable condition for the free development of a person". ${ }^{22}$

20. See e.g. Susan AKRAM, "The Palestinian Statehood Strategy in the United Nations: Lesson from Namibia" Jadaliyya (3 October 20II), online: Jadaliyya <http://www.jadaliyya.com/pages/index/ 2797/the-palestinian-statehood-strategy-in-the-united-n>; Guy GOODWIN-GILL, "Opinion Re The Palestine Liberation Organization, the Future State of Palestine, and the Question of Popular Representation" Jadaliyya (3 I August 20II), online: Jadaliyya <http://www.jadaliyya.com/pages/ index/2 530/guy-s.-goodwin-gill-legal-opinion-on-palestinian-s>; Mutaz M. QAFISHEH, "Bases for the Palestinian Refugees' Right of Return under International Law: Beyond General Assembly Resolution I94" Cambridge Journal of International and Comparative Law Blog (26 November 20I2), online: CJICL < http://cjicl.org.uk/20I2/II/26/bases-for-the-palestinian-refugees-right-ofreturn-under-international-law-beyond-general-assembly-resolution-I94-2/>.

2I. Tang Lay LEE, "Refugees from Bhutan: Nationality, Statelessness and the Right to Return” (I998) Io International Journal of Refugee Law i 8 . See also Bill FRELICK, "For Bhutan's Refugees, There's No Place Like Home" Human Rights Watch (30 March 20II), online: Human Rights Watch < http:// www.hrw.org/news/20I I/o3/30/bhutan-s-refugees-there-s-no-place-home $>$.

22. General Comment No. 27: Freedom of Movement (Art. I2), UN Human Rights Committee, UN Doc. CCPR/C22 I/Rev.r/Add.9 (I999) [General Comment]. 
Under international law, the right is based on a number of sources. A number of scholars have asserted that the right of return, of refugees especially, has attained the status of customary international law, ${ }^{23}$ and as such applies to the Palestinian refugees. In this context, General Assembly Resolution I94 (III) ${ }^{24}$ is widely seen as an affirmation of the existence of the right under customary international law. ${ }^{25}$ Proponents of this view point to state practice as support for their position. ${ }^{26}$ They also point to the fact that this right is expressly recognized in international human rights instruments, state constitutions and local legislation, international humanitarian law, and resolutions of the UN organs. ${ }^{27}$

The flight of the Palestinian refugees occurred during an armed conflict. It was primarily the result of active expulsion by the Israeli army in what can be seen as population transfer or ethnic cleansing. ${ }^{28}$ International humanitarian law, therefore, could be one of the sources for the right of return. ${ }^{29}$ The main source for the right of return under humanitarian law is the Fourth Geneva Convention Relative to the Protection of Civilian Persons in Time of War. Article 45 of the Convention regulates the temporary transfer of protected persons, and requires their repatriation. Article 49 of the Fourth Geneva Convention explicitly prohibits "individual or mass transfer" of protected persons from an occupied territory to another territory or country.

23. Eric ROSAND, "The Right to Return Under International Law Following Mass Dislocation: The Bosnia Precedent?" (I997) I9 Michigan Journal of International Law I I I; Vic ULLOM, "Voluntary Repatriation of Refugees and Customary International Law" (200I) 29 Denver Journal of International Law and Policy I I 5; Alfred de ZAYAS, "The Illegality of Population Transfers and the Application of Emerging International Norms in the Palestinian Context" (I990) 6 Palestinian Yearbook of International Law 17 at 34 .

24. Para. I I of the Palestine-Progress Report of the United Nations Mediator, GA Res. I94 (III), UN Doc. A/RES/I94(III) (I948) [GA Res. I94 (III)], which concerned the war situation in Palestine in I948, provides that the General Assembly:

resolves that the refugees wishing to return to their homes and live at peace with their neighbours should be permitted to do so at the earliest practicable date, and that compensation should be paid for the property of those choosing not to return and for loss of or damage to property which, under principles of international law or in equity, should be made good by the Governments or authorities responsible.

25. Mallison and Mallison, supra note 2 at 28; Lawand, supra note 2 at 544; Bowling, supra note 2 at I 5.

26. The Office of the United Nations High Commissioner on Refugees (UNHCR) statistics show that between the years I 997 and 2006, about II.6 million refugees were able to return home. These include 5.4 million Afghan refugees and I million refugees from Serbia and Montenegro. In the same period, 683,000 refugees returned to Liberia, 529,000 returned to Angola, 504,000 returned to Burundi, and 469,000 returned to Sierra Leone. In 2006 alone, an estimated 734,000 refugees were repatriated to their countries of origin. In contrast, between I 997 and 2006, approximately 838 ,000 refugees were accepted for resettlement programmes in third countries. See UNHCR, "UNHCR Statistical Yearbook 2006: Trends in Displacement, Protection and Solutions" (December 2007), online: UNHCR <http:// www.unhcr.org/ $478 \mathrm{cda} 572 . \mathrm{html}>$ at $36-8$. In other words, for every refugee who had been settled during that period, fourteen refugees were repatriated. These figures reflect an overwhelming preference for return as a durable solution to the refugee problem, so much so that the then UN High Commissioner for Refugees, Ms Sadako Ogata, declared the period beginning in $\mathbf{9 9 9 2}$ as the "decade of voluntary repatriation". See UNHCR, "Introductory Statement by Ms. Sadako Ogata, United Nations High Commissioner for Refugees, to the Informal Meeting of the Executive Committee of the High Commissioner's Programme (ExCom)" (26 June I992), online: UNHCR < http://www.unhcr.org/ cgi-bin/texis/vtx/search?page $=$ search\&docid $=3$ ae 68 fae Ic\&query $=$ decade $\% 200$ \% $\%$ orepatriation $>$.

27. Lawand, supra note 2 at 544 .

28. See Pappe, supra note I.

29. See Quigley, supra note 2 at I97. For a different opinion, see Rex J. ZEDALIS, "Right to Return: A Closer Look" (I992) 6 Georgetown Immigration Law Journal 499. 
Article 49 also requires the repatriation of displaced persons "as soon as the hostilities in the area in question have ceased". $3^{\circ}$

International law recognizes the obligation of states to readmit their nationals. This rule is known as the "readmission rule". States are under an obligation to allow their nationals to return to their territory so that they would not impose a burden on other states hosting them. This obligation is not, however, owed to nationals or refugees. It is invoked in the context of relations between states, and the obligations states owe each other. ${ }^{31}$ Accordingly, states cannot prohibit the readmission of their nationals by denationalizing them. ${ }^{32}$ Several commentators have asserted that, according to the law of state succession, and given their habitual residence in the territory which became Israel in 1948 , Palestinian refugees had ipso facto acquired the nationality of Israel as a successor state. ${ }^{33}$ Their en masse denationalization in I 952 is thus a breach of international law, and Israel has an obligation, which is owed to its neighbouring states, to readmit the Palestinian refugees. ${ }^{34}$

International human rights law is the most explicit and elaborate source for the right of return. Human rights law instruments-which include conventions, general comments of the UN Human Rights Committee, the decisions of the Committee in the communications submitted to it, and decisions by human rights courts and tribunalsdelineate the content and contours of this right in a more detailed manner than other areas of law. This allows for a deeper and more focused analysis of the right, as opposed to the existence of the right as a broad concept or a general principle in other sources.

A number of human rights law instruments contain a provision that protects the right to return to, or to enter and remain in, the state of origin. The most important of these instruments are the Universal Declaration of Human Rights (UDHR), ${ }^{35}$ the International Covenant on Civil and Political Rights, and the Convention on the Elimination of All Forms of Racial Discrimination. ${ }^{36}$ Regional human rights conventions, such as the American Convention on Human Rights, the African Charter on Human and Peoples' Rights, and Protocol No. 4 of the European Convention for the Protection of Human Rights and Fundamental Freedoms, also recognize a right to return. ${ }^{37}$

30. Geneva Convention Relative to the Protection of Civilian Persons in Time of War, I 2 August I949, 75 U.N.T.S. 287 (entered into force 21 October 1950).

3I. Paul WEIS, Nationality and Statelessness in International Law (Alphen aan den rijn: Sitjthoff \& Noordhoff International Publishers, 1979) at 45.

32. Ibid., at 54 .

33. Kattan, supra note 2 at 90-2; Quigley, supra note 2 at 194.

34. The denationalization was the outcome of the enactment of the Citizenship Act-I952 by the Israeli Parliament. According to this Act, the acquisition of citizenship by the non-Jewish residents of Israel was subject to proving uninterrupted residency from the day of the creation of the state in I948 until 1952. This effectively meant that all refugees (and many Palestinians who were not refugees but who could not prove residency) were not entitled to citizenship. See supra note 7 .

35. Universal Declaration of Human Rights, GA Res. 217(III), UN Doc. A/8 Io (I948), art. I3.

36. ICCPR, supra note I2, art. I2; International Convention on the Elimination of All Forms of Racial Discrimination, 2I December I965, 660 U.N.T.S. I95 (entered into force 4 January I969), art. 5(d)(ii), which Israel signed on 7 March 1966 and ratified on 3 January 1979.

37. Art. 22(5) of the American Convention on Human Rights, 2 I November I969, II44 U.N.T.S. I 23 (entered into force I 8 July 1978); art. I2(2) of the African Charter on Human and Peoples' Rights, 
Article I3(2) of the UDHR provides that "[e]veryone has the right to leave any country, including his own, and to return to his country". Article I 2(4) of the ICCPR provides that "[n]o one shall be arbitrarily deprived of the right to enter his own country". Although both provisions essentially deal with the same right, the provisions in both instruments are phrased somewhat differently. The former grants a right to "return", while the latter grants a right to "enter". The former states that the place where the individual should be allowed to return to is "his country", while the latter uses the phrase "one's own country". These differences are not significant, and it is clear from the travaux préparatoires that by using the term "enter" and the phrase "one's own country", the drafters of the ICCPR had intended to broaden the scope of the right as compared to the right in the UDHR. ${ }^{38}$

As opposed to the UDHR, which is non-binding and declaratory in nature, and which was adopted as a UN General Assembly Resolution, ${ }^{39}$ the ICCPR is a treaty that was signed and ratified by most states in the world, ${ }^{40}$ and is therefore binding on those state parties..$^{\mathrm{I}}$ The ICCPR, which was adopted in I966, is a more recent source of law than the UDHR, which was adopted in I948. Article I2(4) of the ICCPR deals with the right to enter one's own country. The right to return could be derived from the right to enter the country, since denying entry or re-entry is the main barrier to return. It is arguable that if a refugee had only one nationality, even if she was stripped of her nationality, she would still have one place where she can call her "own country", which she should be allowed to enter. The acquisition of a new nationality creates a situation where there is another country that a refugee can call her "own country". The question then becomes whether the acquisition of a new nationality extinguishes the right to enter and return to the country of origin. This question will be discussed in Section II.

27 June I98I, I 520 U.N.T.S. 2 I7 (entered into force 2I October I986); art. 3(2) of Protocol No. 4 of the European Convention for the Protection of Human Rights and Fundamental Freedoms, I6 September 1963, Eur.T.S. 46 (entered into force 2 May 1968).

38. See Hurst HANNUM, The Right to Leave and Return in International Law and Practice (Dordrecht: Martinus Nijhoff Publisher, I987) at 59. The Commission on Human Rights, in its 5th, 6th, and 8th Sessions discussed the drafting of art. I2(4) of the ICCPR, especially the issue of which terms to use"return" or "enter", and "country of which he is a national" or "one's own country". It decided to adopt the term "enter" because "[the ICCPR] was intended to cover cases such as those persons born abroad who had never been to the country of their nationality". The phrase "one's own country" was adopted because the phrase "country of which he is a national" would not require states to grant the right of entry to individuals who had established their home there even though they were not nationals. See Marc J. BOSSUYT, Guide to the 'Travaux Préparatoires' of the International Covenant on Civil and Political Rights (Dordrecht: Martinus Nijhoff Publishers, I987) at 26I.

39. Nevertheless, it is widely accepted now that the right of return under the UDHR is customary international law. See Memorial of the United States, Case Concerning United States Diplomatic and Consular Staff in Tehran (US v. Iran), [1980] I.C.J. Pleadings I 82; Theodore MERON, Human Rights and Humanitarian Norms as Customary Law (Oxford: Clarendon Press, I989); Ullom, supra note 23. Other commentators, however, are of the view that there is no sufficient consensus on this point to draw conclusions. See Hurst HANNUM, “The Status of the Universal Declaration of Human Rights in National and International Law" (I995-96) 25 Georgia Journal of International and Comparative Law 346.

40. The ICCPR was signed by I 67 states, and ratified by I 60 states. The number of states that are members of the UN is 192. Israel signed the ICCPR on I9 December I966 and ratified it on 3 October I99I.

4I. According to art. 38 of the Vienna Convention on the Law of Treaties, 22 May I969, I I55 U.N.T.S. $33 \mathrm{I}$ (entered into force 27 January I980), if the rules set forth in a treaty are recognized as customary rules of international law, these rules become binding upon a third state. 


\section{B. A Note on the Time Frame and Relation to Applicable Law}

Due to the long period of time since the flight of the Palestinian refugees in 1948 , one of the issues that should be addressed at the outset is the question of the effect of time in relation to the law. Two relevant issues should be explored. The first is the temporal applicability of international legal norms: What legal rules or principles apply to the situation of the Palestinian refugees, bearing in mind that the displacement took place in I948? Here, I will briefly discuss the rule of inter-temporal law and the different views on the state of the law at the relevant time. Second, I will address the issue of the descendants of the refugees, who were expelled in $1947-49$, who are now second- or third-generation refugees.

The main source articulating the rule of inter-temporal law is the arbitral award in the Island of Palmas Arbitration. ${ }^{42}$ Here, Judge Max Huber stated that "a juridical fact must be appreciated in the light of the law contemporary with it". ${ }^{43}$ Judge Huber then added what is known as the second branch of the rule of inter-temporal law, that:

[t] he same principle which subjects the acts creative of a right to the law in force at the time the right arises, demands that the existence of the right, in other words its continued manifestation, shall follow the conditions required by the evolution of law. ${ }^{44}$

In the context of the Palestinian refugees and their right of return, Victor Kattan provides an elaborate analysis of the temporal issue. ${ }^{45}$ He argues that, in $1947^{-49}$, international law norms banned deportations, in addition to a number of practices that triggered the flight of the Palestinian refugees, such as murder, massacre, rape, pillage, and the destruction of property. This, he argues, rendered the expulsions and the acts that caused the flight of the refugees a breach of international law obligations under international law as it was then. Kattan supports his position by reviewing the jurisprudence of the military tribunals in the aftermath of World War II, including the Nuremberg and the Tokyo Tribunals. ${ }^{46}$ Kattan draws more support for his position by quoting a report prepared by the British Foreign Office regarding the 1948 war, which found that customary international law did apply to that war. This included the norms found in various conventions on international humanitarian law, even though Israel was not a party to them since most of the rules and principles enshrined in them reflected existing customary international law. ${ }^{47}$ Given that the expulsion and the other associated atrocities were illegal at the time they were committed, he argues that Israel committed further violations by the subsequent acts of property confiscation, denationalization, and banning refugees from returning, using violence and other

\footnotetext{
42. Island of Palmas Arbitration (United States $v$. The Netherlands), Award of 4 April I928, [I928] II Reports of International Arbitral Awards 829.

43. Ibid., at 845 .

44. Ibid.

45. Victor KATTAN, From Coexistence to Conquest: International Law and the Origins of the ArabIsraeli Conflict I $891-1949$ (London: Pluto Press, 2009) at 212-I7.

46. Ibid., at $203-8$.

47. Ibid., at 204 .
} 
legislative tools, and therefore Israel's actions amounted to a continuous wrongful act. According to the second branch of the inter-temporal law rule, the relevant law that applies when the conflict is resolved is the law as it developed since the violation first occurred. This means that the sources mentioned earlier in this section are all relevant, even though some of them came into force after the displacement. Kattan also draws further support for his position from Article I 4 of the International Law Commission Articles on Responsibility of States for Internationally Wrongful Acts. Subsection 2 of this Article deals specifically with breaches of international obligations that have a "continuing character", and states that such acts are considered breaches "for the entire period during which the act continues and remains not in conformity with the international obligation"..$^{8}$ Kattan's position is also supported by state practice in the aftermath of World War II, when the majority of the displaced persons were repatriated, some even forcibly. ${ }^{49}$

Contrary to Kattan's position, Andrew Kent argues that Palestinian refugees are not entitled to return because, amongst other reasons, the initial expulsion of 1947-49 was not illegal.5 Kent argues that the Hague Conventions of 1899 and I907 did not apply to the war in I948. ${ }^{5 \mathrm{I}} \mathrm{He}$ further argues that even if Israel was bound by the norms found in the Hague Conventions as part of customary international law, none of the relevant provisions were applicable in the circumstances. ${ }^{52}$ The Hague Conventions, Kent argues, did not apply because the Israeli army, and the pre-state military groups, could not be seen as a hostile occupying army, as per the language used in the conventions. ${ }^{53} \mathrm{He}$ also adds that the territories from which the refugees were expelled were not part of another hostile state that exercised legitimate authority in the area. ${ }^{54}$

There are strong reasons to prefer Kattan's position to Kent's. Kent's arguments suffer from a number of flaws. His reasoning regarding the applicability of customary international law on the laws of armed conflict is very highly formalistic and tries to avoid the substantive legal principles and norms by resorting to a high level of technicality and narrow interpretation. His reasoning is contrary to the spirit of the norms and the texts they are enshrined in, and the manner in which they were applied as early as the I940s. If taken to their logical conclusion, Kent's arguments in effect mean that none of the norms, rules, conventions, or legal principles that govern armed conflict applied to the situation in Palestine in $1947^{-48}$, with the result that

48. Ibid., at 213. Articles on Responsibility of States for Internationally Wrongful Acts, Adopted by the International Law Commission at its 53rd Session on 3 August 200I, Annex to GA Res. 56/83, U.N. Doc. A/56/83 (200I).

49. Daniel COHEN, "Between Relief and Politics: Refugee Humanitarianism in Occupied Germany I945-I946" (2008) 43 Journal of Contemporary History 437.

50. Kent, supra note 3. In a long paper, Kent argues that none of the sources discussed earlier apply to Palestinian refugees. Here I will only focus on his approach to inter-temporal law.

51. Convention (II) Respecting the Law and Customs of War on Land, 29 July I899, 32 Stat. I803, I Bevans 247 (entered into force 4 September 1900); Hague Convention IV-Laws and Customs of War on Land, I 8 October 1907, 36 Stat. 2277, I Bevans 63I (entered into force 26 January I910).

52. Kent, supra note 3 at I80-9I.

53. Ibid., at $185-7$.

54. Ibid., at I87-91. 
Palestine was in some sort of legal vacuum. This was contrary to the reality at the time. Since the second decade of the twentieth century, there has been significant international interest in the legal status of Palestine, and Palestine has been the subject of numerous debates relating to international law, especially in the r940s. Kent's discussion of whether the expulsions of I948 amounted to crimes against humanity is equally not compelling.

There are other grounds to prefer Kattan's position. The discussion here is focused on the issue of human rights. Many human rights violations, as in the case of expulsion and prohibiting return, are "continuing acts". Various human rights bodies and courts have noted that international human rights instruments should be interpreted as "living instruments", with flexible application of the inter-temporal law rule. These bodies, which include the European Court of Human Rights and the Human Rights Committee, ${ }^{55}$ have asserted jurisdiction over, and adjudicated upon, violations that took place prior to the entry into force of various human rights treaties. This was based on the determination that these violations were "continuing acts" which extended over the whole period of time they continued to be in violation of international norms. This has led some scholars to conclude that in the case of human rights violations, the first branch of the inter-temporal principle does not apply, or at least does not apply strictly. ${ }^{56}$

The issue of time also arises in the case of the descendants of the first generation of refugees who were not born in the country of origin, in this case Palestine, or, after I948, Israel. In the context of their right to return, Article I2(4) of the ICCPR uses the term "enter", which is broader than "return". The commentary by the United Nations Human Rights Committee provides that the right to enter one's own country "may also entitle a person to come to the country for the first time if he or she was born outside the country (for example, if that country is the person's State of nationality)". ${ }^{57}$ This understanding is also supported by the travaux préparatoires of the ICCPR..$^{8}$ This position is also supported by the fact that the nationality legislation that was valid in pre-1948 Mandate Palestine, and the Israeli Citizenship Law-I952 are based on the notion of jus sanguinis (nationality based upon the nationality of the parents). Since the denationalization of the Palestinian refugees was illegal under international law, one could argue that the right to return of their descendants is not extinguished by the fact that they were born abroad, and by the fact that they had never set foot in the country. While the passage of time and the fact that they were not born in the country makes their link weaker than the

55. See e.g. Liozidouv v. Turkey (App No I5318/89), [1995] E.C.H.R. IO, (23 March I995); Sandra Lovelace v. Canada, Human Rights Committee Communication No. 24/1977, UN Doc. CCPR/C/I3/ D/24/I977 (I98I); Simunek, Hastings, Tuzilova and Prochazka v. The Czech Republic, Human Rights Committee Communication No. 5I6/I992, UN Doc. CCPR/C/54/D/5I6/I992 (I995).

56. Rosalyn HIGGINS, "Time and the Law: International Perspectives on an Old Problem" (I997) 46 International and Comparative Law Quarterly 50I at 5I7; Paul TRAVERNIER, "Relevance of the Intertemporal Law" in James CRAWFORD et al., eds., The Law of International Responsibility (Oxford: Oxford University Press, 2010), 398 at 402; Jean SALMON, "Duration of the Breach" in James CRAWFORD et al., ibid., 383 at $387-90$.

57. General Comment, supra note 22 at para. 19. See also Akram and Rempel, supra note 2 at 50.

58. Bossuyt, supra note 38 at 26I. 
first-generation refugees, the descendants have maintained strong ties to the area of historic Palestine, as will be explained later in Section III.

\section{THE MEANING OF THE PHRASE "ONE'S OWN COUNTRY"}

The phrase "one's own country" was discussed by the UN Human Rights Committee. ${ }^{59}$ The General Comment states that the phrase "one's own country" is broader than the concept of "the country of nationality", and it is not limited to nationality in a formal sense. The Committee states:

It is not limited to nationality in a formal sense, that is, nationality acquired at birth or by conferral; it embraces, at the very least, an individual who, because of his or her special ties to or claims in relation to a given country, cannot be considered to be a mere alien. This would be the case, for example, of nationals of a country who have there been stripped of their nationality in violation of international law, and of individuals whose country of nationality has been incorporated in or transferred to another national entity, whose nationality is being denied them. The language of article $\mathrm{I} 2$, paragraph 4 , moreover, permits a broader interpretation that might embrace other categories of long-term residents, including but not limited to stateless persons arbitrarily deprived of the right to acquire the nationality of the country of such residence. Since other factors may in certain circumstances result in the establishment of close and enduring connections between a person and a country, States parties should include in their reports information on the rights of permanent residents to return to their country of residence. ${ }^{60}$

The General Comment does not explicitly address the consequences of the acquisition of a new nationality on entering the country of origin, but its special emphasis on special ties or relations to the country does provide some useful insights. The phrase "one's own country" was examined in The Charles E. Stewart v. Canada Communication, and the Oppenheim and Nottebohm cases, which will be discussed below.

\section{A. The Charles E. Stewart v. Canada Communication}

The main case that precipitated the General Comment is the decision of the Human Rights Committee in the Charles E. Stewart v. Canada communication. ${ }^{61}$ In this decision, the Committee decided that the term "one's own country" is broader than the concept of "the country of nationality" and is not limited to nationality in a formal sense. The communication dealt with a situation in which Canada had decided to deport an immigrant, Stewart—a British national—who had lived most of his life in Canada but did not acquire Canadian citizenship, even though there were no impediments to acquiring nationality by immigrants. The Committee decided that Canada could not be seen as "his own country" since Stewart did not apply for formal citizenship, although he was entitled to do so. The Committee thus focused on the fact that he opted not to apply for citizenship. The Committee, however, did not

\footnotetext{
59. General Comment, supra note 22.

6o. Ibid., at para. 20 (emphasis added).

6I. Stewart v. Canada, supra note I7.
} 
mention the fact that he was holding citizenship in another country as grounds for denying him the right to enter Canada. ${ }^{62}$ The Committee stated that:

The question in the present case is whether a person who enters a given State under that State's immigration laws, and subject to the conditions of those laws, can regard the state as his own country when he has not acquired its nationality and continues to retain the nationality of his country of origin. The answer could possibly be positive were the country of immigration to place unreasonable impediments on the acquiring of nationality by new immigrants. But when, as in the present case, the country of immigration facilitates acquiring its nationality, and the immigrant refrains from doing so, either by choice or by committing acts that will disqualify him from acquiring that nationality, the country of immigration does not become "his own country" within the meaning of article I 2, paragraph 4 of the Covenant. ${ }^{63}$

One could infer from the Committee's statement that an immigrant could possibly regard her country of immigration as "her own country" if she was denied citizenship by unreasonable impediments, regardless of the fact that she still holds another citizenship. One could argue that if special ties and relations to a country are proven, the emphasis would shift to the actions of the individual when given the chance to strengthen her relations to "her own country". This means that in order to examine the right of return under the ICCPR, three main factors should be examined. First is the presence of special ties to the country one claims to have the right to return to. The second factor, if special ties exist, is the choices that were available to the individual. That is, if the state had given her the choice of, or facilitated the strengthening of, the special ties and relations. The third factor concerns the decisions and actions of the individual in the light of the choices she was given.

It is argued that a similar rule should be applied to refugees. Refugees who had to flee from their countries and who were arbitrarily denied any chance of returning or re-acquiring their nationality still maintain special ties and claims to their country of origin. The emphasis should, therefore, be on the decisions they made on the basis of the choices that were available to them. Could the acquisition of a new nationality in the case of refugees be seen as a choice not to "strengthen the special ties and relations"? This should be examined in view of the options that were available for them. If the refugee is likely to face the same risk of persecution which had engendered their initial flight, it cannot be argued that the refugee has the option of returning. Indeed, in such a situation, if return is not voluntary in nature, it would be seen as a breach of Article 33 of the I95 I Refugees Convention, which prohibits expulsion or return of a refugee to areas where her life or freedom are at risk. For example, in a case of a refugee whose country of origin is still in a state of war, a meaningful option of returning is denied. In such a case, it cannot be argued that this

62. Ibid. It should be mentioned that in an individual opinion in this Communication (by Elizabeth Evatt and Cecilia Medina Quiroga), the absence of ties to another state was mentioned as one of the factors that should be taken into consideration for deciding which is the "individual's own country". See Charles E. Stewart v. Canada, Individual Opinion by Ms. Elizabeth Evatt and Ms. Cecilia Medina Quiroga, co-signed by Mr. Francisco José Aguilar Urbina, Human Rights Committee Communication No. 538/1993, UN Doc. CCPR/C/58/I993 (I996).

63. Ibid., at para. I2.5 (emphasis added). 
refugee has opted not to strengthen her relations with her state of origin, since this option does not exist in the first place. Another situation is when the reason of the flight does not exist any more, but the government in control of the country of origin is preventing the return of the refugees, as in the case of the Palestinian refugees and the Nepali-speaking refugees from Bhutan. In such an instance, the option for the individual to strengthen the ties with the country does not exist, and therefore the acquisition of a new nationality should not affect her rights to enter her country of origin even if she has lost her formal nationality of that country.

\section{B. The Oppenheim Case}

The notion of personal choice in view of the options available to an individual seeking return to her own country is also supported by another decision. In the Oppenheim case, ${ }^{64}$ the UK House of Lords, in its application of international law principles and the provisions of German legislation on nationality, decided that an illegal deprivation of nationality may become irreversible if the individual voluntarily establishes herself elsewhere at a point when the resumption of the original citizenship would have been possible. Meier Oppenheim, a German-born Jew who had fled to the UK in 1939, was deprived of his German nationality by a decree from I94 I. Given the racist nature of the decree, which was to denationalize only German Jews, the decree was seen as illegal under international law. Oppenheim was subsequently naturalized in Britain. In 1949, as a result of a new provision in German nationality legislation, he was able to reclaim his nationality but opted not to do so. The case dealt with the question of whether Oppenheim was liable to pay UK income tax on certain pension payments, which he had received when he was a British national. According to a tax convention between the German Federal Republic and the UK, such payments would be exempted from tax if Oppenheim were a German national.

Although the deprivation of nationality was illegal under international law, the fact that Oppenheim chose not to reclaim his nationality rendered this illegal act irreversible. In this case, the decisions and the acts of the individual were taken into consideration, in the light of the choices that the individual had. The case emphasizes the possibility of the resumption of the individual's original citizenship. It would be reasonable to argue that, without the ability to resume the individual's nationality, the illegal denationalization would be seen as void, and the individual would still be seen as a national of her state of origin, even if she has subsequently acquired a new citizenship. Brownlie, for example, states that "an illegal deprivation of nationality (for example on a racial basis) may become irreversible if the individual voluntarily establishes herself elsewhere at a stage when 'resumption' of the original citizenship would have been possible". ${ }^{65}$ This means that as long as the resumption of the original citizenship is not possible, the irreversibility of the deprivation of nationality, and in turn the rights that nationality entails, is questionable. Once again, the individual's actions in the light of the options she has are the main points of focus in the analysis.

64. Oppenheim v. Cattermole [1975] 2 W.L.R. 347 (H.L.).

65. James CRAWFORD, Brownlie's Principles of Public International Law (Oxford: Oxford University Press, 2008) at 524 . 


\section{The Nottebohm Case and the "Effective Link Theory"}

Another area which may assist in the determination of the scope of "one's own country" is nationality as understood and interpreted in the context of diplomatic protection. States may only exercise diplomatic protection in respect of their nationals. This highlights the importance of ascertaining the nationality of individuals before states exercise diplomatic protection. Here, issues similar to the one we are dealing with have arisen, namely where it is not clear what nationality an individual has, or in situations where the individual has dual nationality and there is a need to ascertain which nationality would apply for the purpose of diplomatic protection. The authoritative decision of Nottebohm relied on the "effective link theory" ${ }^{66}$ Subsequent decisions on nationality have relied heavily on the "effective link theory", making this theory a general norm of international law. ${ }^{67}$

Friedrich Nottebohm was German by birth. He settled in Guatemala, where he owned a business enterprise, for thirty-four years. In 1939, he applied for naturalization in Liechtenstein and was granted citizenship. In 1943, he was removed from Guatemala, and subsequently his assets and business were expropriated because he was seen as a national of an enemy state-Germany. In the case brought before the International Court of Justice (ICJ) by Liechtenstein, Liechtenstein claimed damages in respect of acts against Nottebohm, who bore its citizenship. Guatemala argued that the case was inadmissible on a number of grounds, including the claim that Nottebohm appeared to have solicited Liechtenstein nationality fraudulently, and with the sole object of acquiring a nationality of a state which was neutral in World War II, and without having any intention to establish a genuine link to the country.

The ICJ decided that there was no bond of attachment between Nottebohm and Liechtenstein. The Court explained that nationality is:

a legal bond having as its basis a social fact of attachment, a genuine connection of existence, interests and sentiments, together with the existence of reciprocal rights and duties. It may be said to constitute the juridical expression of the fact that the individual upon whom it is conferred, either directly by the law or as the result of an act of the authorities, is in fact more closely connected with the population of the State conferring nationality than with that of any other State. Conferred by a State, it only entitles that State to exercise protection vis-à-vis another State, if it constitutes a translation into juridical terms of the individual's connection with the State which has made him its national. ${ }^{68}$

Based on the existence of a "genuine" and "effective" link, the ICJ stated that preference should be given to the "real and effective" nationality. On the question of what is the individual's "real" nationality, the ICJ answered:

the real and effective nationality, that which accorded with the facts, that based on stronger factual ties between the person concerned and one of the States whose nationality is involved. Different factors are taken into consideration, and their importance will vary

66. Nottebohm, supra note I 5 .

67. Ruth DONNER, The Regulation of Nationality in International Law (New York: Transnational Publishers, 1994) at II9.

68. Nottebohm, supra note 15 at 23. 
from one case to the next: the habitual residence of the individual concerned is an important factor, but there are other factors such as the centre of his interests, his family ties, his participation in public life, attachment shown by him for a given country and inculcated in his children, etc. ${ }^{69}$

The ICJ found that Nottebohm had no bond or attachment to Leichtenstein, because his naturalization there was for the sole purpose of "coming within the protection of Liechtenstein but not of becoming wedded to its traditions, its interests, its way of life".$^{\circ}$ On the other hand, the ICJ concluded that he had a long-standing connection with Guatemala, although he did not carry its nationality, a connection which was not weakened by naturalization elsewhere. On an overall assessment of the case, and the principles that the case applies, it is safe to conclude that the focus for the determination of nationality is on the individual's "genuine" connection. The genuineness of the connection does not necessarily mean nationality in the formal sense, but is assessed according to the quality and significance of the individual's links to a given country. When naturalization-which is essentially the acquisition of citizenship - is involved, the ICJ placed special emphasis on the purpose and circumstances of the naturalization. Naturalization is not seen as evidence of the relinquishment of links with other countries that individuals have strong links with.

If such principles were adopted in the case of ascertaining nationality for the purpose of providing diplomatic protection, similar principles can arguably be used in order to ascertain the individual's "own country" according to the ICCPR, since both cases rely on the connection between the individual and the country. Yet such adoption of principles and rules should be done with caution. The determination of nationality for the sake of diplomatic protection should not be the same in international human rights law. Diplomatic protection falls within the realm of relations between states: the determination of nationality is in order to determine whether a state has the right to protect the individual, for example, by representing her in a legal action in an international forum, or by bestowing diplomatic immunity. On the other hand, the determination of nationality, or "one's own country" in international human rights law, falls within the realm of relations between the individual and the state. States are treated as equals in their relations with each other; yet in the relations between the individual and the state, the balance of power always leans towards the state, hence the need for human rights protection for the individual. Any analogy with other areas of law should be done with this asymmetry in mind, and in order to strengthen the protection of the individual's human rights. In accomplishing this, the broad principle of "real or genuine link" can be adopted more generally.

\section{D. "One's Own Country" and the Palestinian Refugees}

This section of the paper has thus far demonstrated that the notion of "one's own country", or even nationality, at least in the context of the ICCPR, is not limited to the formal sense, but is built on the link between the individual and the territory, and

\footnotetext{
69. Ibid., at 22.

70. Ibid., at 26 .
} 
the nature of this link. Emphasis is placed on the strength of the link, the ability to strengthen this link, and on the decisions that the individuals have made, given the options they had. How do these conclusions apply to the issue of the Palestinian refugees, who were displaced in 1948 from Palestine, which no longer exists as a legal entity? In I948, the new state of Israel was formed, and with the end of the war in I949, Israel controlled all of the areas the refugees were expelled from, which became Israeli sovereign territory. This raises the question: What is the "country of origin" of these refugees?

A number of observations will be helpful in determining the "country of origin". While Palestine as a legal entity under the Mandate no longer exists, the geographical area or "the country" — present-day Israel—still exists. In this regard, international law on state succession, ${ }^{71}$ the Mandate nationality legislation in Palestine which was repealed only in $1952,7^{72}$ and to some extent, some Israeli authorities up to the enactment of the 1952 Citizenship Act, ${ }^{73}$ support the assertion that these refugees should be entitled to Israeli citizenship. Even under Israeli law, the idea of "return" does exist and is enshrined in the Law of Return-1950, and does not require any strong links to the country but merely belonging to the Jewish faith. ${ }^{74}$ The idea of return is even a major constitutional principle. ${ }^{75}$ In this sense, the Palestinian refugees still have a strong link to the country which is now Israel, as the successor state of Mandate Palestine, which they see as their "own country". Despite the long period of time since their displacement, most of them, even those who have been naturalized in host countries, still see themselves as Palestinian and many still hope to return to their country of origin. Even though many changes have taken place since I948, and the social, political, and economic situations today differ considerably from the situation in the Palestine of 1948 , this does not mean that the refugees today do not have links to the country of Israel. Most of them still hold ownership deeds over the land that they were expelled from. Some even still have the keys to their houses they left in I948. Most of them still identify with the town or village they or their parents used to live in, and many of them have family members from whom they were separated in I948. The attachment to Palestine as a geographical area that Palestinians see as their

7I. See e.g. Kattan, supra note 2; Quigley, supra note 2.

72. Palestine Citizenship Order, supra note 7. See Mutaz QAFISHEH, The International Law Foundations of Israeli Nationality: A Legal Examination of Nationality in Palestine Under Britain's Rule (Leiden: Martinus Nijhoff Publishers, 2008).

73. Citizenship Act-1952, supra note 7. Between 1948 and I952, there was no citizenship legislation in Israel, and pursuant to s. I I of the Law and Administration Ordinance, No. I of 5708-1948, I9 May I948, Official Gazette, No.2 (21.5.I948), the Palestine Citizenship Order was still valid. A number of decisions by Israeli courts provided conflicting positions on the question of citizenship before the 1952 law. In one case, for example, a judge of the Tel-Aviv District Court relied on public international law and ruled that (A.B. v. M.B., CA $876 / 50,3$ PM, 263 at $27 \mathrm{I}-2$ ):

every individual who, on the day of the establishment of the State of Israel, was resident in the territory which today constitutes the State of Israel, is also a national of Israel. Any other view must lead to the absurd result of a state without nationals.

74. According to the Law of Return-1950 (Statutes Book, 57Io, No. 5I, (6.7.1950), p. I 59), any Jew has the right to immigrate to Israel. A Jew is defined in s. ${ }_{4} \mathrm{~B}$ as "anyone who was born to a Jewish mother, or has converted to Judaism, and is not a member of any other religion".

75. See e.g. the decision of the Supreme Court of Israel in Toshbeim v. Minister of Interior, HCJ 2597/99 (2005), IsrSC 59(3) 721 . 
homeland, which is now under Israeli sovereignty, has played an important role in the shaping and development of the Palestinian national identity. ${ }^{76}$

On the other hand, some commentators, such as Yaffa Zilbershats, have argued that any link that the Palestinian refugees have with Israel is artificial and is superseded by links to the countries they reside in. ${ }^{77}$ This argument, however, ignores the fact the about twenty percent of the population of Israel are Palestinian, many of whom still maintain strong links with the Palestinian refugees, many of whom belong to the same families. It also ignores the fact that the links were weakened due to Israeli official policies and decisions and not because of choices that the refugees made. So far, Israel has been categorically denying the refugees the right to return to their country, ${ }^{78}$ and, therefore they cannot be seen as having the ability to strengthen their links with their country, which is now Israel.

It is important here to recall that the expulsion and the denial of return were part of a racially motivated policy that translated into acts of expulsion and legislative measures to block the return of the refugees in order to maintain a strong Jewish majority in Israel. This goal of a Jewish majority could not have been possible without widespread expulsions, especially since at the time the UN had recommended the partition of Palestine in late 1947 there were more Palestinian Arabs than Jews in the area designated as the Jewish state. ${ }^{79}$ After the displacement, Israel enacted laws in order to freeze the demographic situation at the time, which reduced the Palestinians to a minority of thirteen percent. These included the Absentee Property Act-I950, which confiscated all of the property of the refugees; the Citizenship Act-I952, which officially denationalized all of the Palestinian refugees (even those who were internally displaced); and the Prohibition of Infiltration Ordinance-1954, which was meant to facilitate the expulsion of those refugees who had managed to make their way back to their homes. ${ }^{8 \circ}$ This policy was accompanied by discriminatory policies against the

76. See Rasheed KHALIDI, Palestinian Identity: The Construction of Modern National Consciousness (New York: Columbia University Press, I997); Ahmad SA'DI and Leila ABU-LUGHOD, eds., Nakba: Palestine, 1948 and the Claims of Memory (New York: Columbia University Press, 2007); Efrat BEN-ZE'EV and Issam ABURAYA, “'Middle-Ground' Politics and the Re-Palestinization of Places in Israel” (2004) 36 International Journal of Middle East Studies 639; Randa FARAH, "Palestinian Refugees: Dethroning the Nation at the Crowning of the 'Statelet'?" (2006) 8 Interventions: International Journal of Postcolonial Studies Mediterranean Journal 229; May SEIKALY, "Excavating Memory: Oral History and the Case of Suhmata" in Camille MANSOUR and Leila FAWAZ, eds., Transformed Landscapes: Essays on Palestine and the Middle East in Honor of Walid Khalidi (Cairo: American University in Cairo Press, 2009), I 59; Elias SANBAR, "Out of Place, Out of Time" (200I) I6 Mediterranean Historical Review 87; Mahmoud ISSA, "Resisting Oblivion: Historiography of the Destroyed Palestinian Village of Lubya" (2003) 2I Refuge I4. For personal accounts, see Salim TAMARI and Rema HAMMAMI, "Virtual Returns to Jaffa" (I998) 27 Journal of Palestine Studies 65.

77. Zilbershats, supra note 3 at 202.

78. For a comprehensive review of Israeli positions and policies towards the Palestinian refugee problem, see Nur MASALHA, Politics of Denial: Israel and the Palestinian Refugee Problem (London: Pluto Press, 2003).

79. Kattan, supra note 45 at 164 .

80. Absentees' Property Act-I950 (Statutes Book, 5710, No. 37(20.3.1950), p. 86); Citizenship Act-I952, supra note 7; Prevention of Infiltration (Offences and Jurisdiction) Act-I954 (Statutes Book, 57I4, No. I6I, (26.8.1954), p. I60). It should be mentioned that in addition to expulsion, the Israeli policy was to deter returning refugees by the use of fatal force. Benny Morris observes that by 1956, 2700-5000 refugees were killed trying to return. See Benny MORRIS, Israel's Border Wars, 
Palestinian minority in Israel in almost all areas of life. Many of these policies still persist today, and have even intensified in some areas. ${ }^{81}$ For example, in 2003, Israel enacted the Citizenship and Entry to Israel Act (temporary provision)-2003, which effectively makes family reunification between Palestinians who are Israeli citizens and other Palestinians almost impossible. ${ }^{82}$ The idea of creating and maintaining a Jewish majority is one of the main manifestations of Israel's definition as a Jewish state, and it is seen as one of the cornerstones of the constitutional edifice. ${ }^{8_{3}}$ The policy has a strong racial emphasis, and the Committee on the Elimination of Racial Discrimination has found policies of a similar nature to be a violation of international law. The Committee emphasized that "any attempt to change or to uphold a changed demographic composition of an area against the will of the original inhabitants, by whatever means, is a violation of international law". ${ }^{84}$

After Israel occupied the West Bank and the Gaza Strip in 1967, it extended its racial policies to these areas. Although the occupation was not accompanied by large-scale expulsions, as in I948, many people left the West Bank and Gaza Strip, and were denied return. ${ }^{85}$ Israel also embarked on a large-scale colonization process by settling its population in Jewish settlements in breach of Article 49 of the Fourth Geneva Convention. The settlements and the wall that was constructed to protect them led to further waves of displacement. ${ }^{86}$ In 2004, the ICJ issued its Advisory Opinion on the Legal Consequences of the Construction of a Wall in the Occupied Palestinian Territory, declaring the wall and the settlements illegal, and added that they violated the right of the Palestinians to self-determination. ${ }^{87}$ This strong emphasis on the racial aspects of Israel's policy has led some scholars to argue that the situation should be more accurately described as apartheid. ${ }^{88}$ Given the policy of

1949-1956: Arab Infiltration, Israeli Retaliation, and the Countdown to the Suez War (Oxford: Oxford University Press, I993) at I25-33, I45-7.

8I. See e.g. Sabri JIRYIS, The Arabs in Israel (New York: Monthly Review Press, I976); Ilan PAPPE, The Forgotten Palestinians: A History of the Palestinians in Israel (New Haven: Yale University Press, 20II); Adalah, "The Inequality Report: The Palestinian Arab Minority in Israel" (February 20II), online: Adalah < http://adalah.org/features/misc/Inequality_Report.pdf >; Uri DAVIS, Apartheid Israel: Possibilities for the Struggle Within (London: Zed Books, 2003).

82. The Citizenship and Entry into Israel Law (temporary provision), 5763-2003, 3I July 2003; Mazen MASRI, "Love Suspended: Demography, Comparative Law and Palestinian Couples in the Israeli Supreme Court" (2013) 22 Social \& Legal Studies 309.

83. See the decisions of the Supreme Court of Israel in: Central Elections Committee for the Sixteenth Knesset v. Tibi, EC I I 280/02 (2003), IsrSC 57(4) I; Ben Shalom v. Central Elections Committee, EA 2/88 (I989), IsrSC 43(4) 22I; Galon v. The Attorney General, HCJ 466/o7 (2012).

84. Report of the Committee on the Elimination of Racial Discrimination, Committee on the Elimination of Racial Discrimination, UN Doc. A/50/I 8 (I995).

85. Survey of Palestinian Refugees, supra note I.

86. I949 Geneva Convention (IV) Relative to the Protection of Civilian Persons in Time of War, I2 August I949, 75 U.N.T.S. 287 (entered into force 2I October I950); Mazen MASRI, "Israel's Wall, Displacement, and Palestinian Resistance in the West Bank" in Daniel Coleman et al., eds., Countering Displacements: The Creativity and Resilience of Indigenous and Refugee-ed Peoples (Edmonton: University of Alberta Press, 2012), 59.

87. Legal Consequences of the Construction of a Wall in the Occupied Palestinian Territory, Advisory Opinion, [2004] I.C.J. Rep. I36.

88. John DUGARD and John REYNOLDS, “Apartheid, International Law, and the Occupied Palestinian Territory” (2013) 24 European Journal of International Law 867; Virginia TILLEY, Beyond 
racial discrimination, the demographic policies, the ongoing and even increasing violations, and the obstacles that Israel has mounted in the way of those who want to return, the refugees' naturalization in the country of refuge or in a third country does not, absent the existence of the option to return to Israel, nullify their right of return.

It is important here to highlight that despite the fact that issues of migration and nationality are matters of local law, they are still governed by principles of international law. ${ }^{89}$ Israel cannot rely on its internal legislation, and even its constitutional basic laws that emphasize the idea of the Jewish state in order to evade its obligations under international law. ${ }^{\circ}$ In any event, these issues are not expected to be addressed in any local Israeli court; instead, they are expected to be discussed in negotiations between Israel and the Palestine Liberation Organization, as the political representative of the refugees, and they therefore have to be decided in accordance with international law. Indeed, according to the Oslo Agreement, the question of the refugees is one of the issues to be discussed in the "permanent status" negotiations. ${ }^{\text {I }}$

In this context, it is worthwhile noting the circumstances under which some Palestinian refugees have acquired a new citizenship. As a result of the displacement of I948, Palestinian refugees fled mainly to neighbouring countries, such as Jordan (which after the war included the area known as the West Bank of the Jordan River, which in 1967 was occupied by Israel), Syria, Lebanon, Egypt (including the Gaza Strip which was under Egyptian occupation), and Iraq. Out of these countries, only Jordan granted citizenship to the Palestinians who resided in the Kingdom after the I948 war. This category included refugees (who fled to Jordan and the West Bank) and non-refugees (residents of the West Bank). ${ }^{92}$ In I988, Jordan renounced its claim for sovereignty over the West Bank and severed its legal and administrative links with it, and as a result Palestinians residing there lost their Jordanian citizenship, and Palestinian refugees residing in Jordan were able to maintain their Jordanian citizenship. ${ }^{93}$ This is the biggest category of Palestinian refugees who now hold citizenship of a third state, and they number about 1.75 million. ${ }^{94}$ Another significant

Occupation: Apartheid, Colonialism and International Law in the Occupied Palestinian Territories (London: Pluto Books, 2012).

89. Weis, supra note 3 I at 88.

90. Ibid.; see also Applicability of the Obligation to Arbitrate Under Section 21 of the United Nations Headquarters Agreement of 26 June 1947, Advisory Opinion, [1988] I.C.J. Rep. I 2.

9I. Art. XVII (I)(a), Palestinian-Israeli Interim Agreement on the West Bank \& Gaza Strip, 28 September I995, online: UNSCO <http://www.unsco.org/Documents/Key/Israeli-Palestinian\% 20 Interim \% 20

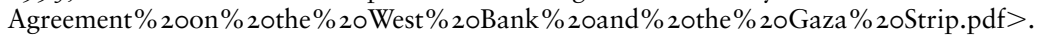

92. Art. 3, Jordanian Nationality Law (1954), Official Gazette no. II7I, p.IO5 (I6.2.1954). See Takkenberg, supra note 4 at I55.

93. Takkenberg, supra note 4 at I 56; Asem KHALIL, "Palestinian Refugees in Arab States: A Rights Based Approach”, CARIM Research Reports (Euro-Mediterranean Consortium for Applied Research on International Migration), 2008-09, 22, online: SSRN <http://ssrn.com/abstract = I 5235 I0 $>$.

94. The total number of Palestinian refugees in Jordan registered with the United Nations Relief and Works Agency (INRWA) is about I.98 million. See UNRWA, "In Figures as of I January 20I2" (January 20I2), online: UNRWA < http://www.unrwa.org/userfiles/20I203I7I 52850.pdf $>$. Out of this number, one should deduct about I 50,000 to account for Palestinian refugees who came to Jordan from the Gaza Strip after the 1967 war. These refugees were not granted Jordanian citizenship. See Khalil, ibid., at 23 . 
group of Palestinian refugees who were given citizenship were wealthy Christian Palestinians in Lebanon. The Lebanese government gave them citizenship in the I950s in an attempt to maintain the demographic balance between Christians and Muslims in that country.95 In the other host countries mentioned above, and other countries that some Palestinian refugees have immigrated to or sought asylum inmainly Europe, North America, and Australia-the grant of citizenship was done on an individual basis as part of the naturalization process. ${ }^{96}$

\section{INTERNATIONAL REFUGEE LAW AND THE CESSATION OF REFUGEE STATUS}

This section of the paper will deal with the impact of the cessation of refugee status on the right of return of Palestinian refugees. It will begin by discussing the particular situation of Palestinian refugees under international law and the applicability of Article ID of the I95 I Convention. A discussion on cessation under Article $\mathrm{I} C$ of the I95I Convention will follow. The rationale for Article $\mathrm{IC}$ and Article I2(4) of ICCPR, and the possible ways of interpreting these provisions, will be examined to ascertain whether the two provisions are contradictory. Based on this analysis, it will be argued that the cessation clause does not necessarily terminate the right of return.

\section{A. Palestinian Refugees and the 195I Convention}

Before proceeding with the analysis of the cessation clauses of the I95 I Convention, one should examine the special situation of the I948 Palestinian refugees under international law, and the applicability of the I95 I Convention. This discussion is needed because opinions on when and how the $195 \mathrm{I}$ Convention applies to Palestinian refugees vary.

Due to the circumstances that led to the creation of the Palestinian refugee problem, Palestinian refugees are treated in a unique manner under the international refugee regime. ${ }^{97}$ With the mass exodus of refugees in 1948 and 1949, the UN General Assembly created two UN bodies to deal with the issue. The first body, created in I948, was the United Nations Conciliation Commission on Palestine (UNCCP). Its mandate included, inter alia, the promotion of "a peaceful adjustment of the future situation in Palestine" ${ }^{98}$ and:

[t]o facilitate the repatriation, resettlement and economic and social rehabilitation of the refugees and the payment of compensation, and to maintain close relations with the Director of the United Nations Relief for Palestine Refugees and, through him, with the appropriate organs and agencies of the United Nations. ${ }^{99}$

95. Takkenberg, supra note 4 at 164 .

96. Khalil, supra note 93 at I9-28; Takkenberg, supra note 4 at I49-91.

97. Akram and Rempel, supra note 2 at 9.

98. Appointment and Terms of Reference of a United Nations Mediator in Palestine, GA Res. I86 (S-2), UN Doc. A/RES/I 86 (S-2) (I948).

99. GA Res. I94 (III), supra note 24. 
Thus, the UNCCP is supposed to have the mandate of protecting Palestinian

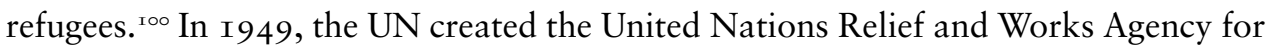
Palestine Refugees in the Near East (UNRWA). UNRWA's mandate was to provide assistance by carrying out a "direct relief and works programme". ${ }^{\text {го }}$ UNRWA's mandate was restricted to assistance, while protection fell within the mandate of UNCCP. ${ }^{102}$ Although the UNCCP still exists officially, it has been defunct since the I960s, and has ceased to fulfil its protection mandate. ${ }^{\text {I03 }}$ This has left the Palestinian refugees with very little protection, creating "a protection gap". ${ }^{104}$

According to Article ID of the I95 I Convention, the Convention does not apply to refugees who receive protection or assistance from other UN agencies other than the United Nations High Commissioner on Refugees (UNHCR). ${ }^{\text {105 }}$ Since other UN bodies deal with the issue of Palestinian refugees, the applicability of the I95 I Convention to Palestinian refugees is unclear. The way this Article applies to Palestinian refugees can be interpreted in a number of ways. ${ }^{106}$ Lex Takkenberg, for example, argues that the first sentence of Article $\mathrm{ID}$, known as the "exclusion clause", means that the 195 I Convention applies to Palestinian refugees falling under the mandate of UNRWA as long as they have the possibility of receiving assistance from UNRWA. Takkenberg's emphasis here is on the possibility of receiving assistance, and not the actual receipt of assistance. He asserts that the second clause, also known as the "inclusion clause", applies only when the possibility of getting assistance from UNRWA ceases to be available. ${ }^{107}$ In such situations, Palestinian refugees, as a category, will be entitled to the benefits of the I95 I Convention without making any determination of whether the refugees meet the criteria of Article IA(2). ${ }^{\text {108 }}$ The UNHCR offers a somewhat different interpretation. According

Iо०. Akram and Rempel, supra note 2 at I9; Takkenberg, supra note 4 at 279. Takkenberg asserts at 280 that:

it may be argued that UNRWA has been providing international protection to the "Palestine Refugees" under its care from the very moment of its establishment. However, in the absence of an explicit protection mandate similar to that of UNHCR, the more traditional aspects of international protection, often referred to as legal and political protection, were for a long time not expressly addressed by the agency.

IоI. Assistance to Palestine Refugees, GA Res. 302 (IV), UN Doc. A/RES/302 (IV) (I949).

I02. Akram and Rempel, supra note 2 at I7.

I03. Ibid., at $2 \mathrm{I}$

I04. Susan AKRAM, "Palestinian Refugees and Their Legal Status" (2002) 3 I Journal of Palestine Studies 42.

I05. Art. ID of the I95I Convention, supra note 5 provides that:

This Convention shall not apply to persons who are at present receiving from organs or agencies of the United Nations other than the United Nations High Commissioner for Refugees protection or assistance. When such protection or assistance has ceased for any reason, without the position of such persons being definitively settled in accordance with the relevant resolutions adopted by the General Assembly of the United Nations, these persons shall ipso facto be entitled to the benefits of this Convention.

I06. For a detailed discussion of art. ID as it applies to Palestinian refugees, see BADIL, "Closing Protection Gaps: Handbook on Protection of Palestinian Refugees in States Signatories to the I95 I Refugee Convention" (August 2005), online: BADIL <www.badil.org>. See also Guy GOODWIN-GILL and Susan AKRAM, "Foreword to Amicus Brief on the Status of Palestinian Refugees Under International Refugee Law" (2000-OI) I I Palestine Yearbook of International Law I 85.

I07. Takkenberg, supra note 4 at Ioo.

Io8. Ibid., at 123 . 
to its Revised Note from 2009, ${ }^{\text {rog }}$ the UNHCR considers the I948 Palestinian refugees, who are inside the area of operations of UNRWA, to fall within the exclusion clause in Article $\mathrm{ID}$, and if a refugee leaves the area of operation of UNRWA for any reason, the refugee will be included in the inclusion clause of Article ID, without having to pass a new assessment under Article IA, regardless of her ability to return to the area of operations of UNRWA. ${ }^{\text {ro }}$

Susan Akram and Terry Rempel, on the other hand, argue that the most appropriate interpretation of Article ID is to view it as a contingent inclusion clause, which will be triggered by the cessation of either protection or assistance by the two UN agencies, UNRWA and UNCCP. Since the UNCCP ceased to fulfil its mandate in the I950s, the I95 I Convention and all of the guarantees and the rights it provides should apply to Palestinian refugees under the inclusion clause in Article ID. ${ }^{\text {II }}$ Akram and Rempel further argue that Palestinian refugees should be entitled to the benefits under Article $\mathrm{ID}$ of the I95 I Convention until their position is "being definitively settled in accordance with the relevant resolutions adopted by the General Assembly of the United Nations”, as per the requirement of Article ID, which in this case means that they are given the option to exercise their rights to return and compensation according to UN General Assembly Resolution I94(III). ${ }^{\text {I2 }}$

To sum up this point, different opinions have been voiced on the question of the applicability of the I95 I Convention to the Palestinian refugees, and the extent and limits of its applicability. Nevertheless, in the absence of a definitive answer on this issue, the I95 I Convention and the cessation clause remain relevant.

\section{B. International Refugee Law and the Focus on Protection}

The main international law instruments that deal with refugees and refugee status are the I95 I Convention and the 1967 Protocol relating to the Status of Refugees. The Statute of the Office of the United Nations High Commissioner on Refugees is also relevant. ${ }^{133}$ The definition of refugee in Article IA of the I95 I Convention includes

I09. UNHCR, "Revised Note on the Applicability of Article ID of the I95 I Convention relating to the Status of Refugees to Palestinian Refugees" (October 2009), online: UNHCR < http://www.unhcr.org/ refworld/docid/4add $77 \mathrm{~d}_{42}$.html $>$. This Note replaced an earlier Note by UNHCR on this issue, see UNHCR, "Note on the Applicability of Article ID of the I95 I Convention relating to the Status of Refugees to the Palestinian Refugees" (October 2002), online: UNHCR < http://www.unhcr.org/cgibin/texis/vtx/refworld/rwmain?page $=$ search\&docid= 3 da I $_{92}$ be $_{4}>$. See also UNHCR, "UNHCR Revised Statement on Article ID of the I95 I Convention" (October 2009), online: UNHCR $<$ http://www.unhcr.org/refworld/pdfid/4add79a8 2.pdf $>$.

I Iо. This is a departure from the UNHCR's past interpretation of art. ID as it applies to the I948 Palestinian refugees. Before the 2002 and 2009 Statements, the UNHCR position was that refugees receiving protection and assistance from UNRWA are excluded by Article ID. However, if the refugee is outside the area of operation of UNRWA, that person "may be considered for determination of his refugee status under the criteria of the I95 I Convention”, that is, under art. IA, para. 2. See paras. I 42-3 of UNHCR, "Handbook on Procedures and Criteria for Determining Refugee Status under the I95 I Convention and the 1967 Protocol Relating to the Status of Refugees” (January I992), online: UNHCR < http://www.unhcr.org/3 $\mathrm{d}_{5} 8 \mathrm{e}_{3} 3 \mathrm{~b}_{4} . \mathrm{html}>$ [Handbook on Procedures and Criteria].

II I. Akram and Rempel, supra note 2 at 67.

II2. Ibid., at 68 .

I13. Protocol Relating to the Status of Refugees, 3 I January 1967, 606 U.N.T.S. 267 (entered into force 4 October I967); UNHCR Statute, supra note 8. 
three key components: fear of persecution, being outside the country of nationality or habitual residence, and lack of protection. ${ }^{\mathrm{II}}$ Refugee law is meant to deal with these three components. The principle of non-refoulement prohibits states from returning individuals who face an actual or well-founded fear of persecution. The other two components, alienage and the lack of protection, are addressed by the international community, which is working collectively to achieve durable solutions for refugees. Durable solutions are meant to provide options for refugees whereby the refugees can find permanent residence and enjoy the protection of a state and cease to be a refugee. This obliges the international community to devote resources to deal with the problems created by the influx of people who are essentially aliens. International law, therefore, sees refugees as a problem for the international community, one that the international community should co-operate in resolving. ${ }^{15}$ Refugee status should be seen as temporary, since it is a problem that should be resolved. It should be seen as an exception to the rule that people should enjoy the protection of their countries. How does cessation affect the other rights of the refugee, especially the right to return to the country of origin? Does cessation terminate or limit that right? In order to answer this question, one needs to examine the meaning of "cessation" and situate the discussion within the objectives and rationale of International Refugee Law (IRL). The interaction between the right of return and IRL should also be examined for inconsistencies and contradictions.

At the heart of refugee law, and as its underlying rationale, lies the principle of protection. Refugee law is meant to determine when refugee status begins-a status which is triggered by alienage and the lack of protection by the state of origin. Once the status is determined, refugee law determines what kind of protection a refugee should be entitled to, the rights of the refugee, and the obligations of the host state until the status ceases. ${ }^{\mathrm{II} 6}$ James Hathaway has put it clearly and succinctly when he said that the main purpose of refugee law:

is to ensure that those whose basic rights are not protected (for a Convention reason) in their own country are, if able to reach an asylum state, entitled to invoke rights of substitute protection in any state party to the Refugee Convention. ${ }^{117}$

Since refugee law sees refugee status as a problem, which is also a temporary phenomenon, it seeks to find permanent solutions for the refugee problem, which would ensure that refugees or former refugees enjoy the necessary protection. ${ }^{\text {I } 8}$

II4. Art. IA(2) of the I95I Convention, supra note 5, defines refugee as any person who: owing to well-founded fear of being persecuted for reasons of race, religion, nationality, membership of a particular social group or political opinion, is outside the country of his nationality and is unable, or owing to such fear, is unwilling to avail himself of the protection of that country; or who, not having a nationality and being outside the country of his former habitual residence as a result of such events, is unable or, owing to such fear, is unwilling to return to it.

II5. See Preamble to the I95I Convention, supra note 5.

I 16. See, for example, arts. I2-43 of the I95I Convention, supra note 5 .

I 7. James HATHAWAY, The Rights of Refugees Under International Law (Cambridge: Cambridge University Press, 2005) at 5 .

I I8. Art. I of UNHCR Statute, supra note 8. 
International law envisages three solutions for the refugee problem that would bring the refugee status to an end: integration in the country of refuge, resettlement in a third country, or voluntary repatriation, with the last being the most desirable solution. ${ }^{119}$ The emphasis is on bringing refugee status to an end by providing a place of residency and protection. None of these instruments explicitly grants refugees the right to return to their own countries or homes. Refugee law mainly calls upon the relevant states to facilitate a solution, be it repatriation or assimilation within new national communities. ${ }^{\text {120 }}$ Out of the three durable solutions, only repatriation represents an absolute obligation on a state, that is, the state of origin. No state is obliged to grant permanent status or citizenship to anyone other than "persons born in its territory who otherwise would be stateless". ${ }^{\text {12r }}$ Resettlement and absorption, therefore, represent discretionary grants of "grace" by the state, not a state obligation, while repatriation is a state obligation. ${ }^{\mathrm{I} 22}$ The fact that return is seen as the most desirable solution does not mean that refugee law is the sole source of that right. It is merely a reflection of what is usually seen as the desires of the refugees and the international community. ${ }^{\mathrm{I} 3}$

Even in the search for permanent solutions for refugees, the focus is mostly on protection. In the area of voluntary repatriation, for example, the focus is on two main points: the voluntary nature of the repatriation, ${ }^{\mathrm{I} 24}$ and the refugee's return in safety and with dignity. Safe return encompasses legal safety, such as "amnesties and personal safety, integrity, non-discrimination and freedom from fear of persecution or punishment upon return". ${ }^{125}$ It also includes physical and material security. ${ }^{126}$ These are all elements of protection. In the area of resettlement and the acquisition of a new nationality, two main points are important to note: the voluntary nature of the

I I9. Marjoleine ZIECK, UNHCR and Voluntary Repatriation of Refugees: A Legal Analysis (The Hague: Martinus Nijhoff Publishers, I997) at I23; Guy GOODWIN-GILL and Jane MCADAM, The Refugee in International Law (Oxford: Oxford University Press, 2007) at 489.

I20. Goodwin-Gill and McAdam, ibid., at 492; Zilbershats, supra note 3 at 209.

I2I. See art. I of the Convention on the Reduction of Statelessness I96I, 30 August I96I, 989 U.N.T.S.I75 (entered into force I3 December I975).

I22. For a different opinion on this point, see Laura Anne REEDS, "Sixty Years in Limbo: The Duty of Host States to Integrate Palestinian Refugees Under Customary International Law" (2006) 8I New York University Law Review 35 I. See also Yaffa ZILBERSHATS, The Human Right to Citizenship (Ardsley: Transnational Publishers, 2002) at I07.

I23. See Preface to the UNHCR, "Handbook on Voluntary Repatriation: International Protection" (April I996), online: UNHCR <http://www.unhcr.org/cgi-bin/texis/vtx/home/opendocPDFViewer.html?docid= 4I64f6404\&query=Handbook\% 200n\% 20Voluntary\% 2oRepatriation:\% 2oInternational\% 2oProtection>; see also Conclusion on Local Integration, No. IO4 (LVI)—2005, EXCOM Conclusions, 7 October 2005, UN Doc. A/AC.96/IO2I (2005).

I24. The reason for focusing on the voluntary nature of return is that in the past, prior to the I95I Convention and the creation of the UNHCR, the general assumption was that all refugees would wish to return home. This was seen as the responsibility of the United Nations Relief and Rehabilitation Administration (UNRRA) that was created in I943. Shortly after UNRRA started its operations, it began facing resistance to repatriation by refugees who had reasons to believe that their place of origin was not safe. This led to debates on the issue and the introduction of the principle that no one should be repatriated against her will. This is the underlying principle behind the focus on the voluntary nature of repatriation. On the evolution of the concept of voluntary repatriation, see generally Zeik, supra note II9 at $4 \mathrm{I}$.

I25. Handbook on Procedures and Criteria, supra note I Io at para. 2.4.

I26. Ibid. 
acquisition of the new nationality ${ }^{\mathrm{I} 27}$ and the effectiveness of the nationality, that is, that it confers protection and rights that are fundamental to nationality. ${ }^{128}$ The voluntary nature of the acquisition of the nationality is important, as involuntary acquisition of nationality does not result in the cessation of the refugee status. ${ }^{129}$

Refugee law, as such, does not explicitly create a right to return which is specific to refugees, but it assumes its existence a priori. Since it already exists under international law, the role of refugee law regarding return is merely to induce the relevant parties to facilitate the voluntary repatriation of the refugees. Therefore, in the absence of any explicit provision, international refugee law instruments cannot be seen as sources of authority to abrogate that right. In fact, the trend that can be identified in the area of refugee law is deference to general human rights law. To this end, the UNHCR Executive Committee has stated that "[s]tates must continue to be guided, in their treatment of refugees, by existing international law and humanitarian principles and practice, bearing in mind the moral dimensions of providing refugee protection". ${ }^{130}$ This is also consistent with the view that sees refugee rights as part of general international human rights law. ${ }^{131}$ As Hathaway has put it: "[r]efugee rights do not exist as an alternative to, or in competition with, general human rights. Nor, however, has the evolution of a broad-ranging system of general human rights treaties rendered the notion of refugee-specific rights redundant." ${ }_{{ }_{32}}$

Article $\mathrm{IC}(3)$ of the $\mathrm{I} 95 \mathrm{I}$ Convention provides that the application of the Convention will cease if the refugee acquires a new nationality and enjoys the protection of the country of nationality. Again, we see that the emphasis is on the protection and the extent to which the new nationality can provide protection. This reinforces the assertion that the main focus in the I95I Convention is on protection, and that the cessation of the refugee status only examines and deals with the protection and its quality. ${ }^{133}$ Other paragraphs of Article ${ }_{\mathrm{I}} \mathrm{C}$ also highlight the issue of protection. For example, paragraph I states that the re-availment of the refugee of the protection of her country of nationality will bring the refugee status to an end. Paragraph 5 provides that compelling reasons, arising out of previous persecution, for the refugee's refusal to avail herself of the protection of the country of nationality are an exception for the cessation of the refugee status because of the change of circumstances in the country of nationality. A similar exception also exists in paragraph 6, which deals with refugees who do not carry the nationality of their country of origin, but who are only habitual residents. Paragraph 2, which focuses on

I27. UNHCR, “The Cessation Clauses: Guidelines on Their Application” (April r999), online: RefWorld $<$ http://www.refworld.org/docid/3co6I38c4.html >.

I28. Goodwin-Gill and McAdam, supra note I 9 at 138 .

I29. James HATHAWAY, The Law of Refugee Status (Toronto: Butterworth, I99I) at 2 Io.

I30. UNHCR, "General Conclusion on International Protection No. 50 (XXXIX)—I988 EXCOM Conclusions" ( 10 October I988), online: UNHCR <http://www.unhcr.org/3ae68c95Io.html> at para. C.

I3I. Hathaway, supra note II7 at 5 .

I32. Ibid., at 75 .

133. I95I Convention, supra note 5. See generally Joan FITZPATRICK, "The End of Protection: Legal Standards for Cessation of Refugee Status and Withdrawal of Temporary Protection” (I999) I3 Georgetown Immigration Law Journal 343. 
the re-acquisition of nationality, also implicitly deals with protection, since nationality and the re-acquisition of nationality constitute the supreme manifestation of the reavailment of protection of the country of origin. ${ }^{34}$ It is clear that the underlying rationale behind this clause is to determine when a refugee ceases to be in need of international protection, and when the "refugee problem" comes to an end. It is not intended to have any implications on the rights the refugee had before becoming a refugee.

\section{Interpretation of the $195 \mathrm{I}$ Convention and the ICCPR: Contradiction or Harmony?}

As opposed to the I95 I Convention, which deals with the relationship between the refugee and the country of refuge, Article I2(4) of the ICCPR deals with a right that is triggered by the arbitrary action of the refugee's state of origin, which denies the refugee the right to enter the country. The Article's focus is on the issue of freedom of movement and the relationship between the individual and the country she resides in, and the obligations that are imposed on states as a result of this link. The right, in this situation, is invoked vis-à-vis the state of origin. It is therefore clear that the I95 I Convention and the ICCPR are meant to serve different objectives and functions, and protect different interests, although there may be some, albeit minimal, overlap between them. Therefore, there is no contradiction in asserting that an individual retains the right to return even if her refugee status has been terminated. It may be the case that the lack of any apparent contradiction is the reason why authors who have written in support of the applicability of Article I2(4) of the ICCPR did not feel compelled to examine the impact of the cessation on the right of return. On the other hand, an argument can be made that the acquisition of a new citizenship terminates the right of return of the former refugee to her country of origin. Lewis Saideman argues, based on his perceived contradiction between two treaty provisions, that:

[c]onventions and laws in general ought to be interpreted in a plain language manner that harmonizes them rather than in a manner that places them at odds with each other. If a refugee has accepted new nationality, he now has a place that he can "enter" and call home; his new state of protection is his "own country". ${ }^{\mathrm{I} 35}$

From the outset, it should be explained that, as shown above, there is no conflict between Article I 2(4) of the ICCPR and Article IC of the I95 I Convention, since the I95 I Convention contains no provision abrogating the right of return. Nevertheless, even if a conflict does exist, does the interpretation that Saideman offers, which terminates the right to return, adhere to the rules of interpretation of treaties under international law? As shown in the analysis below, the answer is "no".

The interpretation of treaties is governed by the Vienna Convention on the Law of Treaties. $^{136}$ The treaty is seen, more or less, as a restatement of customary

\footnotetext{
I34. I95I Convention, supra note 5; Goodwin-Gill and McAdam, supra note I 9 at I38.

I35. Saideman, supra note 3 at 863 .

136. Vienna Convention on the Law of Treaties, 22 May I969, I I 55 U.N.T.S. 33 I (entered into force 27 January I980).
} 
international law, ${ }^{137}$ and is ratified by I08 states. ${ }^{138}$ Article $3 \mathrm{I}(\mathrm{I})$ of the Vienna Convention provides that "[a] treaty shall be interpreted in good faith in accordance with the ordinary meaning to be given to the terms of the treaty in their context and in the light of its object and purpose”. Article $3 \mathrm{I}(2)$ stipulates that the context for the purpose of interpretation shall include, inter alia, the text, the preamble, and the annexes. The context of the ICCPR, as can be understood from its text and the preamble, is the guarantee, protection, and promotion of human rights in general, with a special emphasis on civil and political rights. Also, another leading principle in the interpretation of human right treaties, especially the ICCPR, is that provisions permitting derogations from rights and limitations on rights, should be construed in a strict and narrow manner. ${ }^{\mathrm{I} 9}$ So even if the cessation clause is treated as a limitation clause, its scope and interpretation should be construed in a strict and narrow manner.

With respect to the I95 I Convention, apart from the fact that it does not contain any provision indicating that cessation of refugee status can affect the right of return of the refugee, the preamble of the Convention begins by considering the "principle that human beings shall enjoy fundamental rights and freedoms without

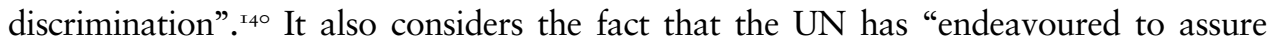
refugees the widest possible exercise of these fundamental rights and freedoms". ${ }^{14 \mathrm{I}}$ This emphasis on human rights shows that the object of the Convention is to provide humans with further rights, or create refugee-specific rights, but not to abrogate rights already in existence. Therefore, Article IC of the I95 I Convention should not be construed in a way that limits and restricts human rights that were granted by other international law instruments. ${ }^{\mathrm{I} 2}$

Saideman further elaborates on this issue, and argues that even if a refugee is seen as having two nationalities, the acquisition of a new citizenship brings to an end the right of return to the state of origin. His argument is based on the assertion that international law does not compel recognition of dual citizenship, and even tries

\footnotetext{
I37. Crawford, supra note 65 at 368 .

I38. UN, "Multilateral Treaties Deposited with the Secretary General”, online: UN < http://untreaty.un.org/ ENGLISH/bible/englishinternetbible/partI/chapterXXIII/treatyı.asp >.

I39. Hannum, supra note 38 at 23.

I40. Preamble to the I95I Convention, supra note 5.

I4I. Ibid.

142. See e.g. Salahadin Abdulla and Others $v$. Bundesrepublick Deutschland, Decision by the Court of Justice of the European Union, C-I75/08, C-I76/o8, C-I78/o8, C-I79/08 at paras. 53-4. See also Suresh v. Canada (Minister of Immigration and Citizenship), (2002) S.C.C. I, [2002] S.C.R. 3. In this case, the Minister of Immigration and Citizenship was requesting the deportation of a Convention refugee from Sri Lanka, despite the fact that it was likely that the refugee would be subjected to torture if deported. On the issue of refugee-specific rules and general human rights, the Court said, at para. 72 , that:

In our view, the prohibition in the ICCPR and the CAT [Convention Against Torture] on returning a refugee to face a risk of torture reflects the prevailing international norm. Article 33 of the Refugee Convention protects, in a limited way, refugees from threats to life and freedom from all sources. By contrast, the CAT protects everyone, without derogation, from statesponsored torture. Moreover, the Refugee Convention itself expresses a "profound concern for refugees" and its principal purpose is to "assure refugees the widest possible exercise of ... fundamental rights and freedoms" (Preamble). This negates the suggestion that the provisions of the Refugee Convention should be used to deny rights that other legal instruments make universally available to everyone.
} 
to limit it. ${ }^{\mathrm{I} 33} \mathrm{He}$ further argues that "the increasing phenomenon of toleration of dual citizenship does not indicate a widespread subjective sense of legal obligation on the part of states, but appears to be a gratuitous gesture by willing nations". ${ }^{144}$ Saidemen concludes that since recognition of dual citizenship is only permissible under international law and is not a right, "Article I2(4) of the ICCPR ought to be interpreted to grant an individual a right to call only one country 'his own' ". ${ }^{145}$ He does not, however, provide any reason as to why dual citizenship should not be recognized under the ICCPR, even though it is permissible under international law. In addition, this argument seems to be outdated, and ignores the fact that nationality in the context of international human rights law is not nationality in the formal sense, but an effective and genuine link between the country and the individual. His assertions regarding dual citizenship do not reflect a rule of general international law. Although some treaties regard the restriction of the ability to have more than one nationality as desirable, and strive to reduce multiple nationalities, ${ }^{\mathrm{r} 46}$ there are other treaties that tolerate multiple nationalities, and others that even encourage dual nationality. ${ }^{\mathrm{I} 7}$ Thus, the treaties, which seek to restrict multiple nationalities, are seen as particular international law, ${ }^{\mathrm{T} 48}$ and cannot be seen as a rule of general international law. International law on this point appears to be neutral. The argument, therefore, that the right of return can only be limited to one state because international law does not create an obligation to recognize multiple citizenship is not supported by the recent trends in the area. Such an interpretation also ignores the human rights context. The argument becomes even harder to sustain given that Israel itself tolerates multiple citizenship.

In conclusion, the interpretation that Saideman provides cannot stand. The method of interpretation used, and the assertions and assumptions made, are contrary to universally accepted rules of interpretation, and contrary to the principles and objectives of both Conventions. In fact, the proposed interpretation (which supposedly would result in greater harmonization of international law) comes with many risks. Refugee law aims at providing protection to refugees until their "refugee problem" is solved. It is also seen as a temporary status, until the "refugee problem" is solved and adequate protection is provided. To this end, the reduction of the number of refugees in the world by offering durable solutions is described as one of the goals of the UNHCR. ${ }^{149}$ At the same time, many refugees insist on returning to

\footnotetext{
I43. Saideman, supra note 3 at 865 .

I44. Ibid., at 865 .

I45. Ibid.

146. See, for example, The Convention on Reduction of Cases of Multiple Nationality and Military Obligations in Cases of Multiple Nationality, 6 May 1963, 634 U.N.T.S. 22I (entered into force 28 March 1968). This Convention was later amended and the requirements for allowing multiple nationalities according to the Convention were relaxed. See also Second Protocol Amending the Convention on the Reduction of Cases of Multiple Nationality and Military Obligations in Cases of Multiple Nationality, 2 February 1993, I967 U.N.T.S. 338 (entered into force 24 March 1995).

I47. Donner, supra note 67 at 203.

I48. Weis, supra note 3 I at 199.

I49. Art. 8(b), Statute of the Office of the United Nations High Commissioner for Refugees, provides that (UNHCR Statute, supra note 8):

The High Commissioner shall provide for the protection of refugees falling under the competence of his office by:
} 
their state of origin, and refuse any other option that would risk their right to return. Harmonization in the manner proposed by Saideman may deter such refugees, who desire to return to their homes, from seeking to improve their situation and give up their status as refugees by acquiring a new nationality because this would compromise their ability to return to their country of origin.

If, for the sake of harmonization, refugees who wish to acquire a new nationality would be deprived of their right to return to the state of origin, many refugees may opt not to acquire a new nationality, and thus preserve their status as refugees, a status that is seen as "a problem" and that international law aims at eradicating. Harmonization in this manner would decrease the number of refugees who would opt to terminate their refugee status, which would be at odds with the object of the I95 I Convention itself. This kind of harmonization would punish the refugee for attempting to improve her situation. It is also in contradiction with the principles and goals of the international refugee law system. In addition, the position suggested is flawed because it ignores the other different sources of law of the right of return. ${ }^{\text {iso }}$

\section{CONCLUSION}

The issue raised in this paper deals mainly with the relationship between international refugee law and general human rights law. Although the emphasis is on Palestinian refugees, this question is relevant in the context of refugees who have been in exile for a long period of time, and seek to improve their situation by being naturalized in another state. It arises in a more acute way in situations of ethnic cleansing, or situations where the state of origin is not interested in repatriation because of the ethnicity, race, or social or group class of the refugees. Classic examples are conflicts that are ethnic or national in nature, especially in the context of state succession, where issues of nationality become complex.

The right of return to one's own country, especially a refugee's right of return, goes beyond the concept of citizenship or nationality. It is focused on the link between the individual and the territory, and on the interest of the individual in having a safe space in which to live and thrive. Sometimes, like in the situation of naturalization in a different country, this link is somehow weakened. In such situations, the weakening of the link should not automatically lead to a deprivation of rights. This is especially true in the case of refugees. The circumstances that led the refugees to leave their country of origin, the circumstances blocking their return, and the decisions made by the individuals in view of their available options, should be examined. If the country of origin did not allow, or facilitate, the strengthening of relations with it, it would be difficult to argue that the individual has lost her link with that country, and thus the right to enter it. The right to return, therefore, is not contingent on formal

(b) Promoting through special agreements with Governments the execution of any measures calculated to improve the situation of refugees and to reduce the number required protection.

I 50. In his paper, Saideman evaluates the different sources of law for the right of return, and concludes that the only one that applies in the case of the Palestinian refugees is the ICCPR, which is probably why he did not discuss the impact of the other sources of law in his analysis. This position, in my opinion, is fundamentally mistaken. 
nationality, but on a strong link between the individual and the territory. The fact that this link is weakened due to restrictions and measures by the state cannot be used to abrogate the link and the rights that stem from this link.

The abrogation of the right of return, therefore, with all of the implications that it has for the link between the individual and the territory, is not a simple issue, and cannot be determined without taking into consideration the circumstances that caused the refugee's departure and those that are blocking her return. The right is independent of refugee status, even though it becomes more important and relevant in the case of refugees. Since the right of return is independent of refugee status, the cessation of the latter should not necessarily abrogate the former. Although refugee status is governed by refugee law, and at the same time the refugee is entitled to exercise the right to return under the ICCPR, this overlap should not be seen as a contradiction that needs to be reconciled. The two tools aspire to achieve different ends and protect different interests, and hence do not clash. One cannot expect that, with the cessation of the refugee status, the refugee would relinquish all legal, social, and spiritual links with her country of origin. It is hard to conceive of the legal status of individuals as encompassing all aspects of her life, and as the determinate factor in deciding her belonging and links. Similarly, it would be naive and even ridiculous to see the acquisition of a new nationality as an event that "resets" the human experience, and as an event that transcends human belonging, social links, culture, and life.

As James Hathaway argued, refugee law is not an alternative or a competitor to general human rights law. This notion is well supported by the refugee law instruments and the practices of the international organizations dealing with refugees. This notion should be the guiding principle when dealing with the interaction between refugee law and general human rights law. 